Journal: $\quad$ European Journal of Soil Science

Pages: $\quad 15$

Figures: $\quad 3$

Tables: $\quad 4$

S Figures 2

S Tables: $\quad 18$

Title:

Alkalinity movement down acid soil columns was faster when lime and plant residues were combined than either applied separately.

Running title:

Alkalinity movement down acid soil columns

Authors:

Clayton R Butterly ${ }^{1,2^{*}}$, Brendon Costello ${ }^{1}$, Dominic Lauricella ${ }^{1}$, Peter Sale ${ }^{1}$, Guangdi Li $^{3}$ and Caixian Tang ${ }^{1 *}$

Institute/s:

${ }^{1}$ Department of Animal, Plant \& Soil Sciences, Centre for AgriBioscience, La Trobe University, Melbourne, Vic 3086, Australia

${ }^{2}$ School of Agriculture and Food, Faculty of Veterinary and Agricultural Sciences, The University of Melbourne, Parkville, Vic 3010, Australia

${ }^{3}$ NSW Department of Primary Industries, Wagga Wagga Agricultural Institute, PMB, Pine Gully Road, Wagga Wagga, NSW 2650, Australia

*Corresponding authors:

Clayton Butterly

clayton.butterly@unimelb.edu.au

This is the author manuscript accepted for publication and has undergone full peer review but has not been through the copyediting, typesetting, pagination and proofreading process, which may lead to differences between this version and the Version of Record. Please cite this article as doi: $10.1111 /$ ejss.12945

This article is protected by copyright. All rights reserved. 
Tel +61 390354228

\section{Caixian Tang}

C.Tang@latrobe.edu.au

Tel +61 390327416

\section{Keywords}

amelioration; crop residue; leaching; soil pH; subsoil acidity 


\section{Summary}

Subsurface soil acidity is a serious constraint to crop production and is inherently difficult to correct through conventional application of lime. Thus, new approaches to ameliorate subsurface soil acidity are needed. A column leaching experiment was established to determine whether the plant residues, when combined with lime, could facilitate lime dissolution and alkalinity movement down soil columns (10 cm in diameter $\times 45$ cm long) to ameliorate acid subsurface soil layers. Five plant residues from canola (Brassica nappus L.), field pea (Pisum sativum L.), lucerne (Medicago sativa L.), oats (Avena sativa L.) and vetch (Vicia villosa L.) (C/N ratios of 52, 13, 16, 53 and 12, respectively) were mixed with soil (18 g dry matter $\mathrm{kg}^{-1}$ ) in the top of soil columns $(0-10 \mathrm{~cm})$ either limed (target $\mathrm{pH} 7$ in $\left.\mathrm{CaCl}_{2}\right)$ or non-limed and incubated for 3 months at $25^{\circ} \mathrm{C}$. Soil columns were leached 6 times over the 3-month incubation period and destructively sampled at 1 and 3 months for chemical analysis. The soil amended with plant residues created favourable $\mathrm{pH}$ gradients and facilitated downward movement of alkalinity when lime was added. However, net increases in $\mathrm{pH}$ in 10-12 cm layer after 3 months were only observed in two non-legume residue amended treatments (canola and oat residues, 0.22-0.43 pH unit increase), but not in three legume residue amended treatments (field pea, lucerne and vetch residues) although those treatments had the greatest $\mathrm{pH}$ increase in short-term (1 month). In conclusion, surface incorporation of lime in combination with plant residues accelerated the amelioration of subsurface acidity in the immediate zone $(10-12 \mathrm{~cm})$ below the amended layer. Canola and oat residues were superior in terms of increase soil $\mathrm{pH}$ over a longer term (3 months) possibly due to their higher $\mathrm{C} / \mathrm{N}$ ratios.

\section{Highlights}

- Can plant residues, combined with lime, facilitate alkalinity movement down soil columns?

- Few studies have examined leaching, alkalinity movement and $\mathrm{pH}$ gradients using agricultural soils.

- Lucerne and vetch had the greatest pH increase (1 month) but canola and oat persisted (3 months).

- Alkalinity movement was faster when lime and plant residues were combined that applied alone.

\section{Introduction}

Soil acidification is a major cause of agricultural land degradation throughout the world (Noble \& Sumner, 2003). In Australia, acid soils ( $\mathrm{pH} \leq 5.5$ ) are estimated to cover at least 50 million ha of surface soils and 23 million ha of the subsoils, with much of this occurring in agriculturally productive land (de Caritat et al., 2011). Soil acidification is a naturally occurring process that develops relatively slowly, often taking hundreds or thousands of years to develop (Noble \& Sumner, 2003). However, soil acidification can occur at a faster 
rate in agricultural systems as a result of farming practices, such as redistribution and removal of alkalinity and the use of $\mathrm{NH}_{4}$-based fertilisers (Barak et al., 1997; Tang et al., 2013). Acid soils are usually synonymous with poor crop performance and although they may present several challenges, it is the increased concentration of soluble $\mathrm{Al}^{3+}$ that is considered the most common constraint to plant growth (Ryan, 2018). $\mathrm{Al}^{3+}$ rapidly inhibits root cell expansion, elongation and eventually division (Matsumoto, 2000). Reductions in the amount and function of roots limit access to water and nutrients (Kochian et al., 2004) and often mean that crops do not achieve their yield potential.

The processes that drive surface soil acidification and subsequent management practices have been well described (Helyar \& Porter, 1989; Scott et al., 2000). However, there has been less focus on the processes that drive acidification of subsurface soil layers (below the cultivated layer) (Tang et al., 2013). Subsurface soil acidity is widespread in farming systems (Paul et al., 2003) and can develop within 5 years under specific crop rotations (Burle et al., 1997). Although acid subsurface layers only occupy a narrow zone, they should not be overlooked as they can inhibit root penetration and thus access to non-acidic subsoils (Doss \& Lund, 1975). The rate at which subsurface soil acidification develops depends on the initial soil $\mathrm{pH}$, fertility, fluctuations of soil moisture content and $\mathrm{pH}$ buffering capacity (Paul et al., 2003). In farming systems acidification mainly occurs by imbalances in the carbon (C) and nitrogen $(\mathrm{N})$ cycles through the uneven cation/anion uptake by plants, the removal of alkalinity in farm products and nitrate leaching (Tang et al., 2013). Generally, plants will take up nutrient cations and extrude $\mathrm{H}^{+}$to maintain an internal charge balance. Similarly, when a nutrient anion is taken up the root will extrude an $\mathrm{OH}^{-} / \mathrm{HCO}_{3}{ }^{-}$(Rengel \& Tang, 2003). The relative number of ions assimilated and extruded depends on the plant species and the nutrient concentration of the soil. When plants take up more cations than anions, net rhizosphere acidification occurs (Tang et al., 1997). Returning plant residues to the soil in which they were grown can result in zero net acidification in the absence of other acidifying processes. However, in most farming systems part or all of the plant is removed at harvest, resulting in the acidification of soil (Rengel \& Tang, 2003).

Currently, the most common and effective method of managing soil acidity is the addition of lime $\left(\mathrm{CaCO}_{3}\right)$ to raise soil pH (Ryan, 2018). Lime is usually broadcast on soil surface as the costs associated with deep incorporation are high and it may also cause unwanted mixing of nutrient-rich surface soil with infertile subsoil. Lime dissolution is a slow process governed by initial soil $\mathrm{pH}$, moisture content and lime particle size (Nye \& Ameloko, 1987). Due to its low solubility, the downward movement of lime below the amended layer is slow (Liu \& Hue, 2001; Li et al., 2019). It is also dependent on soil type and texture, which may increase the instances whereby undissolved lime particles are able to move downward by mass flow and may be feasible in sandy soils (Whitten et al., 2000). Moreover, for alkalinity to move into subsurface layers it requires lime to be added in far greater quantities than the lime required to neutralise acidity in the $0-10 \mathrm{~cm}$ layer 
(Cregan et al., 1989). Such high rates can be cost prohibitive if lime needs to transport long distances and problematic if alkaline soil conditions are then induced in the topsoil before lime moves further down the profile.

Plant residues can have an acid-neutralising effect when they decompose and thus may also be used to manage acid soils (Wong \& Swift, 2003; Wang et al., 2017). Under warm moist conditions, decomposing plant residues are involved in a number of abiotic and biological processes resulting in a net increase in soil pH (Haynes \& Mokolobate, 2001). This is a function of an initial increase in soil pH upon plant residue addition due to the flow of protons from the soil solution to newly added exchange sites found on the organic matter (Tang \& $\mathrm{Yu}, 1999$ ), the net change in $\mathrm{H}^{+}$concentration from $\mathrm{N}$ cycle processes, ammonification, nitrification, immobilisation/uptake and any subsequent nitrate $\left(\mathrm{NO}_{3}^{-}\right)$leaching (Hedley \& Bolan, 2003) and increases in $\mathrm{pH}$ from the $\mathrm{C}$ cycle process, microbial decarboxylation. However, the magnitude of any $\mathrm{pH}$ increase varies between plant residues and is dependent on their alkalinity content (organic anion content), which is estimated by the concentration of excess base cations (Pocknee \& Sumner, 1997; Tang \& Yu, 1999; Wong et al., 2000) as well as their $\mathrm{C} / \mathrm{N}$ ratio that controls the rate of plant residue decomposition and the relative contributions of $\mathrm{N}$ and $\mathrm{N}$ cycles to $\mathrm{pH}$ change (Butterly et al., 2011; Wang et al., 2013). In addition to increasing $\mathrm{pH}$, organic residue additions have been shown to decrease concentrations of soluble $\mathrm{Al}^{3+}$ (Bessho \& Bell, 1992; Wong et al., 1995) by forming complexes with solid-phase organic matter and soluble organic acid anions, greatly reducing the concentration phytotoxic forms (Haynes \& Mokolobate, 2001).

Plant residues have also been shown to produce alkalinity below the layer in which they are applied (Butterly et al., 2013). This is due to the leaching of organic compounds and organic acids that generate alkalinity by decarboxylation as well as increases in $\mathrm{pH}$ via ammonification and the uptake or immobilisation of $\mathrm{NO}_{3}{ }^{-}$that has moved down the profile after being generated in the layers above. While these processes are capable of ameliorating subsurface acidity, the effect can be transient and re-acidification may occur if $\mathrm{NH}_{4}{ }^{+}$ is assimilated by microbes or leached from the amended layer and net nitrification occurs in the subsurface soil. Previous studies have shown that only materials with higher $\mathrm{C} / \mathrm{N}$ ratio were able to increase subsoil $\mathrm{pH}$ (Wang et al., 2016). The addition of organic residues with lime may be able to increase the concentration of base cations and reduce the $\mathrm{pH}$ gradient between the amended layer and that below that is sufficient enough to allow unreacted dissolution products of lime to leach into the subsurface soil and provide a more long-lived increase in $\mathrm{pH}$ (Miyazawa et al., 2002). While mixing alkaline by-products with plant residues showed potential to ameliorate acid soils (Li et al., 2015; Wang et al., 2016), few studies have investigated the combined effects of plant residues and agricultural lime (Whitten, 2002).

The aim of this experiment was to determine the relative effectiveness of plant residues differing in alkalinity content and $\mathrm{C} / \mathrm{N}$ ratio on the downward movement of and its dissolution products, and subsequent 
changes in $\mathrm{pH}$ and $\mathrm{Al}^{3+}$ concentrations. We hypothesised that (a) plant residues would facilitate the downward movement of alkalinity from lime creating increased $\mathrm{pH}$ at depth, and (b) the magnitude of lime movement and subsequent $\mathrm{pH}$ change below the amended layer would be greater for plant residues with higher excess cation concentration (alkalinity content) and lower $\mathrm{C} / \mathrm{N}$ ratio (faster decomposition).

\section{Materials and methods}

\section{Soils and amendments}

Soil was collected at 0-8 cm (topsoil) and 8-15 cm (subsurface soil) from a Luvisol, World Reference Base (WRB, 2014) or Chromosol, Australian Soil Classification (Isbell, 1996) at Rutherglen, Victoria, Australia $\left(36^{\circ} 03^{\prime} 20^{\prime \prime} \mathrm{S} 146^{\circ} 27^{\prime} 45^{\prime \prime} \mathrm{E}\right)$. Soils were sieved (<2 mm), thoroughly mixed and air-dried. The soil had a silty loam texture with the initial $\mathrm{pH}_{\mathrm{CaCl}_{2}}$ of 5.2 and 4.7 for the topsoil and subsurface soil, respectively. Importantly, this soil is not naturally acidic in the subsoil, but has developed an acidic subsurface layer due to management practice over the past few decades. Key soil chemical properties are outlined in Table 1.

Plant residues of canola (Brassica nappus L.), field pea (Pisum sativum L.), oats (Avena sativa L.) and vetch (Vicia villosa L.) were collected from fields directly at various locations after harvest. The commercially pelletised lucerne (Medicago sativa L.) hay was also included as it was one of the soil amendments used in the field experiments in the same project. All plant residues were dried at $70^{\circ} \mathrm{C}$ and finely ground ( $<2 \mathrm{~mm}$ ) using a Retsch ZM200 centrifuge mill (Retsch GmbH, Haan, Germany). These materials were chosen because they are readily available to growers from the grain-growing belt of south-eastern Australia. Chemical properties of the plant residues are outlined in Table 2.

\section{Column incubation experiment}

An incubation experiment consisted of six plant residue treatments (five types of plant residue and a non-plant residue control) and two lime levels (+ lime versus - lime) with three replicates. Soil columns were reconstructed using topsoil at 0-10 cm and subsurface soil at 10-40 cm (Figure 1). The PVC columns (10 cm in diameter and $45 \mathrm{~cm}$ high, IPLEX Pipelines, Australia) were longitudinally sectioned and rejoined with tape and silicone (Figure 1). The base of the column contained a $125 \mathrm{~mm}$ Whatman GF/A glass microfiber filter held within a plastic frame $(10 \mathrm{~cm}$ in diameter $\times 2.5 \mathrm{~cm}$ high) with fine nylon mesh $(3.5 \mu \mathrm{m}$, Sefar Pty Ltd, Australia) over a funnel filled with QENOS Alkamax low-density polyethylene (LDPE) beads, which were washed in $5 \% \mathrm{HCl}$ and rinsed thoroughly in reverse osmosis water. The beads provided structural support to 
the glass fibre filter to prevent cracking. Soil columns were packed by first filling the base of each column (10-40 cm) with subsurface soil and lightly tapping to achieve a bulk density of $1.4 \mathrm{~cm} \mathrm{~cm}^{3}$. The intersect between the two soil layers at 10-cm was marked by placing a small number of LDPE beads on the top of the subsurface soil. The beads were used as the reference point when sectioning the soil columns to ensure the plant residue interface was correctly located and errors associated with changes in density between amended layers were eliminated. Then, topsoil with and without amendments, was added to the top of each column (0$10 \mathrm{~cm})$.

Plant residues (18 g dry matter $\mathrm{kg}^{-1}$ ) were mixed with soils from the $0-10 \mathrm{~cm}$ layer either limed (to achieve pH 7 in the amended layer) or non-limed before being transferred to the top of each column. The lime $\left(\mathrm{CaCO}_{3}\right)$ used was F70 Superfine (OMYA, Australia). The soil columns were wet to field capacity, loosely covered to minimize evaporation and allowed to stand in a controlled environment room (CER) at $25^{\circ} \mathrm{C}$.

The soil columns were leached with Milli-Q water approximating the pore volume of the $0-10 \mathrm{~cm}$ amended layer. In total, six leaching events were performed at 1 week (366 ml, equivalent to $45 \mathrm{~mm}$ 'rain'), and 2, 4, 7, 10 and 13 weeks (300 ml, equivalent to $37 \mathrm{~mm}$ 'rain'). Clear tubing (8-mm PVC, Pope Industries) was attached to the base of each column to direct leachate into individual containers. The mass, $\mathrm{pH}$ and electrical conductivity (EC) of the leachate were determined immediately at each leaching event, before freezing. Then, the columns were loosely covered to minimize evaporation and tubing was removed from the base of each column leaving them to drain freely, equivalent to $100 \%$ water-holding capacity or field capacity (opening of the funnel, $<1.5 \mathrm{~cm}$ ). Some columns required a mild vacuum to be applied at the base to completely drain the added water (if leaching took $>10 \mathrm{~h}$ ), and this was most prevalent at the initial leaching event. Notably, water movement through the soil columns improved in each subsequent leaching event.

\section{Soil sampling}

Soil columns were destructively harvested after 1 month and 3 months of incubation. Each column was sectioned into 0-10, 10-12, 12-15, 15-20, 20-30 and 30-40 cm layers. Smaller depth increments below the amended layer were used to enable increased precision of soil chemical changes down the soil column. Samples were oven-dried at $40^{\circ} \mathrm{C}$ and were well-mixed to ensure homogeneity before chemical analysis.

\section{Chemical analyses}

Initial soil pHCaclz and pH buffer capacity (pHBC) were quantified according to Wang et al. (2015). Total C and $\mathrm{N}$ concentrations of soil and plant residues were determined by dry combustion on finely ground air-dried 
samples (CHNS $\backslash O$ Analyser 2400 Series II, PerkinElmer, Waltham, USA). Concentrations of total Ca, K, Mg, $\mathrm{Mn}, \mathrm{Na}, \mathrm{P}, \mathrm{S}, \mathrm{Al}, \mathrm{Fe}, \mathrm{Cu}$ and $\mathrm{Zn}$ within plant residues were determined using inductively coupled plasma optical emission spectroscopy (ICP-OES) (Perkin Elmer Optima 8000, USA) following digestion with nitric:perchloric acids (4:1). The excess cation content of the plant residues, calculated as the difference in charge concentration between cations $\left(\mathrm{Ca}^{2+}, \mathrm{Mg}^{2+}, \mathrm{K}^{+}\right.$and $\left.\mathrm{Na}^{+}\right)$and anions $\left(\mathrm{SO}_{4}{ }^{2-}\right.$ and $\left.\mathrm{PO}_{4}^{-}\right)$(Tang \& $\mathrm{Yu}$, 1999) was used to estimate the alkalinity content.

Immediately following leachate collection, $\mathrm{pH}$ and EC were determined, leachate volume was estimated by weight and the solutions were subsequently stored at $-20^{\circ} \mathrm{C}$ until further analysis. The $\mathrm{pH}$ was quantified using a combination glass electrode (HI1043, Hanna Instruments, USA) and pH meter (Thermo Orion 720A+, Beverly, MA, USA) and EC using a MeterLab CMD210 (Radiometer, Copenhagen, Denmark). Soils (18 g) were extracted with $0.01 \mathrm{M} \mathrm{CaCl}_{2}$ (1:5) using an end-over-end shaker for $1 \mathrm{~h}$, then centrifuged at $839 \times g$ for $5 \mathrm{~min}$. The $\mathrm{pH}$ of each soil extract was determined before aliquots were filtered for subsequent analyses. Dissolved organic carbon (DOC) was quantified using a Sievers InnovOx ES TOC analyser after passing the 1:5 $\mathrm{CaCl}_{2}$ extracts through 0.45- $\mu \mathrm{m}$ syringe filters (Millex-HV PVDF, Merck Millipore, USA). Monomeric aluminium $\left(\mathrm{Al}^{3+}\right.$ ) was determined using the Pyrocatechol Violet (PCV) method of Conyers et al. (1991). Briefly, a 1-ml aliquot of each extract filtered through $0.22 \mu \mathrm{m}$ (Millex-GP PES, Merck Millipore, USA) was mixed with $167 \mu 10.1 \% \mathrm{w} \mathrm{v}^{-1}$ orthophenanthroline $+10 \% \mathrm{w} \mathrm{v}^{-1}$ hydroxylamine hydrochloride, 167 $\mu 10.1 \%(\mathrm{w} / \mathrm{v})$ pyrocatechol violet and $3 \mathrm{ml} 10 \%(\mathrm{w} / \mathrm{v})$ ammonium acetate buffer $(\mathrm{pH} 7)$ and allowed to stand for 1 hour. Al concentrations were then quantified spectrophotometrically at $580 \mathrm{~nm}$. The concentration of $\mathrm{Al}$, $\mathrm{Mn}$ and $\mathrm{P}$ in soil extracts, and $\mathrm{Ca}, \mathrm{Mg}, \mathrm{S}, \mathrm{K}, \mathrm{Na}, \mathrm{Al}, \mathrm{Mn}, \mathrm{P}, \mathrm{Zn}, \mathrm{Cu}$ and Fe in leachates were determined via ICP-OES. Absolute amounts of cations and anions leached from each soil column were then calculated as the sum of each element leached (concentration $\times$ volume) at each sampling time.

\section{Statistical analysis}

For each depth, a two-way analysis of variance in a completely randomised design was conducted to test effects of plant residues, lime and their interactions on soil $\mathrm{pH}$, DOC, monomeric $\mathrm{Al}$ and cation/anions within soil extracts, and cation/anions in leachates using GenStat $18^{\text {th }}$ edition (VSN International, Hemel Hempstead, England). A least significant difference (LSD) at $P=0.05$ was used to test differences between treatment means.

\section{Results}


After 1 month, all plant residues significantly increased soil $\mathrm{pH}$ in the $0-10 \mathrm{~cm}$ layer $(P \leq 0.05)$ with the largest increase being for vetch residue $(0.71 \pm 0.075 \mathrm{pH}$ units, mean \pm standard deviation) and the smallest for oat residue $(0.31 \pm 0.147 \mathrm{pH}$ units) (Figure 2, Table 3). Similarly, plant residues + lime treatment increased $\mathrm{pH}$, again with vetch showing the largest increase $(1.45 \pm 0.245 \mathrm{pH}$ units $)$ and oats the smallest $(1.25 \pm 0.063 \mathrm{pH}$ units). It is clear that all plant residue + lime treatments increased soil $\mathrm{pH}$ more than the corresponding plant residue treatment alone. However, this increase was mainly due to the lime $(0.97 \pm 0.138 \mathrm{pH}$ units). The greatest increase in $\mathrm{pH}$ between lime only and the lime with residue treatments was $0.48 \pm 0.188 \mathrm{pH}$ units for the vetch with lime treatment.

All treatments increased soil $\mathrm{pH}$ below the amended layer $(10-12 \mathrm{~cm})$, indicating a downward movement of alkalinity (Figure 2, Table 3). The greatest increase in $\mathrm{pH}$ was from vetch residue ( $\mathrm{pH}$ $6.74 \pm 0.141)$, which was significantly $(P \leq 0.05)$ higher than vetch residue + lime (pH 6.43 \pm 0.197$)$. Lucerne + lime increased $\mathrm{pH}$ to 6.68 being more than lucerne alone ( $\mathrm{pH}$ 6.31), and this was the only treatment that addition of lime significantly increased soil $\mathrm{pH}(P \leq 0.05)$ compared with the corresponding non-limed treatment in the 10-12 cm layer. However, in the absence of lime, all plant residue treatments increased the soil $\mathrm{pH}$ in the 10-12 cm layer more than that of corresponding treatments in the 0-10 cm layer. Below $12 \mathrm{~cm}$, the $\mathrm{pH}$ gradually decreased in all treatments highlighting a diminishing effect of the treatments on $\mathrm{pH}$ with depth. Only lucerne + lime showed a significant difference in $\mathrm{pH}(P \leq 0.05)$ with the corresponding plant residue alone treatment, being $0.7 \pm 0.274$ of a $\mathrm{pH}$ unit higher between layers of $15-20 \mathrm{~cm}$ and $20-40 \mathrm{~cm}$. However, it should be noted that there was no significant effect of lucerne + lime on $\mathrm{pH}(P>0.05)$ when compared with vetch + lime and field pea + lime, it is simply because lucerne residue alone did not increase $\mathrm{pH}$ as much as these other plant residues at this depth.

The large differences between the amended soils and the non-amended control observed at 1 month had largely diminished by 3 months (Figure S1, Table S3). In the 0-10 cm layers this was due to the increase in $\mathrm{pH}$ of the nil control $(0.39 \pm 0.059 \mathrm{pH}$ units) but no re-acidification occurred in the amended layer. In contrast, 10-12 cm layers of legume-residue-amended soils did re-acidify after 1 month of incubation. At the end of the study at 3 months, only field pea, vetch and lucerne residues had a significantly higher $\mathrm{pH}$ than the non-residue-amended control $(P \leq 0.05)$. Increases in $\mathrm{pH}$ of the nil control below the amended layer $(10-40 \mathrm{~cm})$ were observed throughout the column. The increase of $1.19 \pm 0.208 \mathrm{pH}$ units occurred in the 10-12 cm layer and $0.72 \pm 0.193 \mathrm{pH}$ units in the $15-20 \mathrm{~cm}$ layer. As a result, only canola and oats residues + lime treatments showed significant increase in $\mathrm{pH}(P \leq 0.05)$ below the amended layer at $10-12 \mathrm{~cm}$ when compared to the 
corresponding plant residue treatment alone, although the effect of plant residue was not significant $(P=0.08)$ when including all plant residue treatments. There was no significant $(P>0.05)$ difference in $\mathrm{pH}$ between plant residues alone and the nil control. Full ANOVA data is provided in Table S1.

\section{Soil dissolved organic $C$}

The DOC concentration in the 0-10 cm layer at 1 month was greater in the plant residue and plant residue + lime treatments than the non-amended control and lime only treatment (Figure 3, Table 3). The highest concentration of DOC was observed with vetch + lime $\left(237 \pm 11 \mu \mathrm{g} \mathrm{g}^{-1}\right)$, with all plant residue + lime treatments producing significantly more DOC than the corresponding non-limed treatments $(P \leq 0.05)$, except for lucerne residue. The relative magnitude in DOC concentration between the plant residue + lime treatments decreased in the following order, vetch $>$ oats $>$ field pea $>$ lucerne $>$ canola. Similarly, at $10-12 \mathrm{~cm}$, all treatments except lime only treatment producing greater DOC than the non-amended control, indicating a downward movement of DOC below the amended layer. Lucerne + lime was the only plant residue + lime treatment to have significantly more DOC below the amended layer $(10-20 \mathrm{~cm})$ than the corresponding non-limed treatment $(P \leq 0.05)$. Full ANOVA data is provided in Table S2.

At 3 months, all treatments except vetch (both limed and non-limed) had higher concentrations of DOC than the nil control (Figure S2, Table S3). However, the DOC concentration of all treatments decreased when compared to that at 1 month. The largest decrease was observed for vetch + lime (-76\%) and the smallest decrease for canola (-44\%). At 10-12 cm, directly below the amended layer, canola + lime and oat + lime were the only treatments to have significantly more DOC than the corresponding non-limed treatments $(P \leq 0.05)$. However, all treatments except vetch had a higher DOC concentration than the nil control. From 12-40 cm, there was no significant effect of any treatment on DOC concentration $(P>0.05)$.

\section{Soil monomeric Al}

In the amended topsoil layer $(0-10 \mathrm{~cm})$, the concentration of monomeric Al was low $\left(<0.3 \pm 0.0032 \mathrm{mg} \mathrm{kg}^{-1}\right)$ prior to incubation and remained that way throughout the experiment. However, although the total concentration of monomeric $\mathrm{Al}$ was low below the amended layer $\left(<1.3 \mathrm{mg} \mathrm{kg}^{-1}, 12-15 \mathrm{~cm}\right)$, the treatment difference was significant $(P<0.05)$. At 1 month, the monomeric $\mathrm{Al}$ was reduced to $\leq 0.03 \pm 0.0133 \mu \mathrm{g} \mathrm{g}^{-1}$ in the limed and non-limed canola-residue treatments (Table 4). This reduction was greater than that of lime alone with a final concentration being $0.35 \pm 0.0283 \mu \mathrm{g} \mathrm{Al} \mathrm{g}$. There was no significant difference between 
plant residues + lime and plant residues alone $(P>0.05)$. At 3 months, there was no significant treatment effect on $\mathrm{Al}$ concentrations ( $P>0.05$, Table S5). Full ANOVA data is provided in Table S4.

\section{Leachates}

In general, the $\mathrm{pH}$ of leachates was not affected by the treatments in the soil columns, except for the 2-week leaching event (Table S6). Specifically, the $\mathrm{pH}$ of the leachate collected from canola, field pea and vetch residue-amended columns were $0.34 \pm 0.106,0.4 \pm 0.090$ and $0.3 \pm 0.136 \mathrm{pH}$ units higher than that in the nil control, respectively. Notably, $\mathrm{pH}$ of the leachates generally increased with each leaching event albeit highly variable. Similarly, the EC of leachates at week 1 (mean $1.26 \pm 0.313 \mathrm{dS} \mathrm{m}^{-1}$ ) was greater than all other sampling times $\left(<0.8 \pm 0.185 \mathrm{dS} \mathrm{m}^{-1}\right.$ ) (Table S7). The effect of treatments on leachate EC was highly variable, but generally EC was greater for plant residue + lime treatments than plant residues alone, and differences between plant residue treatments were small, albeit significant except for 2 weeks. Therefore, the relative differences in leachate EC between treatments did not indicate major dissimilarities in the amounts of cations and anions leached.

The concentration of $\mathrm{Al}$ in the leachates peaked at week 2 for all plant residue and plant residue + lime treatments, except non-limed canola which peaked at week 4 (Table S8). The greatest Al concentration was observed in the non-limed vetch and field pea treatments. Al concentration remained low for all other leaching events. A similar pattern was observed in the limed and nil-control, however the peak in $\mathrm{Al}$ concentration was delayed when compared with plant residue treatments, occurring at week 4 and week 7 for the limed and nil-control, respectively (Table S8).

Fe concentration in leachates displayed the same pattern across all treatments as that of Al. However, leachates from non-limed and plant residue + lime treatments of oats and lucerne pellets contained subsequent peaks in concentration of greater magnitude than the initial peaks at weeks 7 and 10, respectively (Table S9). For all treatments, Mn concentrations of leachates, including the limed and nil-control were initially low, however the concentrations increased each week from week 7 to week 13 (Table S11)

Concentrations of $\mathrm{Ca}, \mathrm{Cu}, \mathrm{K}, \mathrm{Mg}, \mathrm{Mn}, \mathrm{Na}, \mathrm{S}$ and $\mathrm{Zn}$ in leachates were high at week 1 , the highest being $\mathrm{Ca}$ in non-limed canola and remained low for all subsequent leaching events, which was similar across all plant residue + lime and non-limed treatments, including the limed and nil-control (Tables S10, S11, S12, S13, S14, S15, S17 and S18). P concentration in leachates was negligible $(<0.35 \pm 0.0882 \mathrm{mg}$ total) (Table S16).

It should be noted that canola and oat-residue-amended columns had higher concentrations of all divalent cations, which was not consistent with initial concentrations in the materials (Table 2). Furthermore, 
cation concentrations were significantly $(P<0.05)$ greater in the limed treatments compared to non-limed treatments. For example, $\mathrm{Ca}$ and $\mathrm{Mn}$ concentrations were 2 times greater and $\mathrm{Mg}$ was 1.5 times greater on the limed treatment than non-limed treatments (Tables S10, S13, S14).

\section{Discussion}

\section{Soil $p H$}

This study showed that plant residues were able to facilitate the downward movement of alkalinity after a 1month incubation. Below the amended layer, only lucerne + lime displayed significant greater $\mathrm{pH}$ when compared with the corresponding plant residue only treatment. However, this did not represent a greater $\mathrm{pH}$ increase of this treatment than other plant residue + lime treatments, but that lucerne residue alone had little effect on soil pH below $15 \mathrm{~cm}$. In fact, the vetch + lime treatment had a negative effect on pH directly below the amended layer when compared with vetch-residue alone. Except for lucerne, the development of $\mathrm{pH}$ gradients down the profile at 1 month for plant residue + lime treatments was likely an effect from the plant residues and not from lime. After 3 months, treatment effects below the amended layer were minimal due to the reacidification of the 10-12 cm layer of legume-residue-amended treatments as well as an increase in $\mathrm{pH}$ of the nil control. The latter could have been due to denitrification of $\mathrm{NO}_{3}{ }^{-}$if anaerobic conditions occurred during the leaching events but this was not quantified in the current study.

Soil pH changes in the plant residue-amended layers observed here were typical of that seen by plant residues in other studies (Paul et al., 2001; Xu et al., 2006; Butterly et al., 2013; Wang et al., 2013). The pH changes induced by the addition of plant residues is a function of abiotic and biological processes, the latter involving the net change in $\mathrm{pH}$ associated with $\mathrm{H}^{+}$-consuming ammonification, $\mathrm{H}^{+}$-producing nitrification, and consumption of $\mathrm{H}^{+}$ions by microbial decarboxylation (Yan et al., 1996) as well as the rate of release and concentrations of base cations. Vetch, which induced the greatest $\mathrm{pH}$ increase of all the plant residues, had the lowest $\mathrm{C} / \mathrm{N}$ (11.8:1) and also the greatest excess cation concentration of the plant residues in this study. Nitrogen-rich plant residues are expected to decompose faster, and net ammonification during the mineralisation of organic $\mathrm{N}$ may result in a $\mathrm{pH}$ increase, i.e. ammonification being greater than nitrification. It is likely that 3 months is sufficient time for the decomposition of such plant residues to maximize net effect on $\mathrm{pH}$ (Butterly et al., 2011). It should be noted that if $\mathrm{NH}_{4}{ }^{+}$were leached from the layer where ammonification takes place, it would result in a net increase in $\mathrm{pH}$. However, $\mathrm{NH}_{4}{ }^{+}$leaching is not likely the main mechanism responsible for this $\mathrm{pH}$ change. The concentration of excess cations of a particular plant residue must also be 
considered when determining the magnitude of the effect on $\mathrm{pH}$. The internal charge imbalance due to excess cation uptake in plants is balanced by the synthesis of organic acid anions (Rengel \& Tang, 2003). These organic anions are the substrate for microbial decarboxylation and their concentration brings about differences in pH change (Yan et al., 1996). The plant residues used in this study differed considerably in the concentration of organic anions (estimated as excess cations) (Table 2). In the current study, vetch residue had the highest excess cation concentration ( $169 \mathrm{cmol} \mathrm{kg}^{-1}$ ) and canola residue had the lowest excess cation concentration (54 cmol kg-1), which was consistent with the greatest and smallest increases in $\mathrm{pH}$, respectively.

Soil pH increased in the amended layer of all plant residue + lime treatments, and this increase was greater than corresponding plant residues alone and the lime only control. The $\mathrm{C}$ and $\mathrm{N}$ mineralisation are known to be highly $\mathrm{pH}$ dependent and microbial processes in the $\mathrm{C}$ and $\mathrm{N}$ cycles inhibited by low $\mathrm{pH}$. Also, C-use efficiency is thought to be lower in acid soils as $\mathrm{C}$ is used for energy at the cost of cell growth (Stotzky \& Norman, 1961; Bertrand et al., 2007). In this study, greater microbial activity with lime and plant residue addition increased DOC concentrations in plant residue + lime treatments more than corresponding non-limed treatments. Soil microbes exude exoenzymes capable of hydrolysis and dissolution of large organic molecules and solid state organic matter (Marschner \& Kalbitz, 2003). The resulting products of this are represented as DOC, which is the most important C source for microorganisms (Marschner \& Bredow, 2002). Increases in the size and activity of the microbial community should facilitate decarboxylation of DOC and be associated with greater increases in $\mathrm{pH}$. The rate of $\mathrm{pH}$ change differs for each plant residue depending on the $\mathrm{C} / \mathrm{N}$ ratio and the amount of soluble organic compounds, which in turn influences the rate of decomposition (Butterly et al., 2011). Changes in $\mathrm{pH}$ are expected to induce feedback to soil microorganisms with the biochemical cascade influencing the community composition and function of successive populations (Ratzke \& Gore, 2018).

Although the actual role of biological and chemical process is unclear, greater increases in pH of plant residues + lime compared to lime alone may indicate that unreacted lime or its dissolution products $\left(\mathrm{CO}_{3}{ }^{2-}\right.$ and $\mathrm{HCO}_{3}^{-}$) to move below the amended layer. Miyazawa et al. (2002) demonstrated that oats + lime significantly increased the $\mathrm{pH}$ below the layer of application when compared with the corresponding nonlimed treatment after 25 months. However, that study had a longer incubation time and a coarser textured soil with increased drainage compared with the current study. Nevertheless, the combination of plant residues + lime may provide higher concentrations of organic anions, inorganic ion pairs or $\mathrm{CO}_{3}{ }^{2-}$ and $\mathrm{HCO}_{3}{ }^{-}$as well as an excess of $\mathrm{Ca}^{2+}$ from lime that enable greater leaching of these down the soil profile than either of the plant residues or lime added alone. We intentionally limed the topsoil to achieve $\mathrm{pH}$ 6.5-7 as other studies have shown that maintaining $\mathrm{pH}$ above 5.5 is essential to neutralise acidity within the amended layer and facilitate alkalinity movement down soil profile (Li et al., 2019). 
Lucerne residue + lime increased pH below the amended layer $(10-12 \mathrm{~cm})$ at 1 month compared with lucerne alone. This is promising, suggesting the possibility that lime and/or alkaline products generated after lime dissociation moved down the profile. Lucerne had the highest $\mathrm{S}$ concentration of all the plant residues. $\mathrm{Li}$ et al., (2015) showed that $\mathrm{SO}_{4}{ }^{2-}$ was an important ion pair that facilitated the downward movement of base cations (predominantly $\mathrm{Ca}^{2+}$ from lime in this study) that then promoted $\mathrm{H}^{+}$and $\mathrm{Al}_{3}{ }^{+}$to leach further into the subsoil. Greater increases in $\mathrm{pH}$ in the 10-12 cm layer compared with the 0-10 cm layer are likely due to the lower pHBC of the subsurface soil (Magdoff \& Bartlett, 1985). Firstly, it is important to consider that lucerne was the only plant residue included in this study to have undergone a form of processing, being pelletised under high pressure steam, which may have caused chemical changes. The lower $\mathrm{pH}$ of the lucerne-amended soils may represent nitrification of leached $\mathrm{NH}_{4}{ }^{+}$(leached as $\left(\mathrm{NH}_{4}\right)_{2} \mathrm{SO}_{4}$ ), which may lead to net reacidification. However, this was phenomenon not observed for vetch residue that had high $\mathrm{S}$ and a much greater $\mathrm{N}$ content. The ability of the lucerne + lime to resist this change may indicate that lime has moved down the profile, increasing $\mathrm{pH}$ and DOC. It is also possible that the DOC concentration of the lucerne + lime amended layer was much greater during the early stages of the study and rapid decomposition meant this was already depleted prior to 1 month. Thus, the subsequent increase in $\mathrm{pH}$ may be due to increased downward movement of $\mathrm{Ca}^{2+}$ from lime, DOC and the associated microbial decarboxylation (Marschner \& Kalbitz, 2003).

\section{Soil monomeric Al}

Monomeric Al concentrations were much lower than expected and were reduced to almost zero by 1 month. The initial low monomeric Al concentration was likely due to an increase in subsurface soil $\mathrm{pH}$ from that tested in the field before collection. Therefore, only small increases in $\mathrm{pH}$ were needed to completely hydrolyse monomeric $\mathrm{Al}$, and the decrease seen in this study is likely due to the increase in $\mathrm{pH}$. However, DOC can also detoxify $\mathrm{Al}^{3+}$ by complexing $\mathrm{Al}$, and may also be responsible for the reduced monomeric $\mathrm{Al}$ concentration (Hue \& Licudine, 1999). At 3 months, concentration of monomeric Al throughout the soil columns remained negligible. However, this shows that if only small increases in $\mathrm{pH}$ are needed to ameliorate $\mathrm{Al}^{3+}$ toxicity in the subsurface layer of moderately acid soils, then plant residues may be sufficient to achieve this even in the absence of lime.

\section{Conclusion}


Plant residues with greater excess cation concentrations and lower $\mathrm{C} / \mathrm{N}$ ratios (vetch, lucerne) showed the greater increases in $\mathrm{pH}$ (1 month) but reacidified with higher $\mathrm{C} / \mathrm{N}$ ratio residues canola and oat being superior in terms of soil $\mathrm{pH}$ increase over a longer term (3 months). This study demonstrated that plant residues + lime can generate alkalinity below the amended layer, create favourable $\mathrm{pH}$ gradients and may facilitate the downward movement of alkalinity from lime. The relative effect of plant residues + lime on $\mathrm{pH}$ below the amended layer is likely due to excess cation and $\mathrm{N}$ concentration of plant residues. Greater leaching of $\mathrm{Ca}^{2+}$, organic anions, inorganic ion pairs or $\mathrm{CO}_{3}{ }^{2-}$ and $\mathrm{HCO}_{3}{ }^{-}$down the soil profile as well as less acidification via the $\mathrm{N}$-cycle may have resulted in greater increases in $\mathrm{pH}$ below the amended layer with plant residues + lime than when these were added alone. Unfortunately, the gradual increase in $\mathrm{pH}$ of the nil controls and reacidification of 10-12 cm layers of legume-residue-amended soils meant that treatment effects were minimal at 3 months. Further work is required to determine if the $\mathrm{pH}$ increase below the amended layer is transient or whether it persists. Although monomeric Al concentration was low, we showed that even small increases in $\mathrm{pH}$ may reduce $\mathrm{Al}^{3+}$ toxicity and that plant residues may be suitable amendments in cropping soils that have relatively low levels of acidity, higher initial pH and lower pHBC than more acid soils found elsewhere.

\section{Acknowledgments}

This work is part of a GRDC project (DAN00206) investigating innovative approaches to managing subsoil acidic in the southern grain region of Australia. We thank Dr Han Weng for reviewing the manuscript, Dr Jason Condon for allowing access to the Rutherglen experimental site for soil collection and Chris Krohn for help with construction of the leaching columns. The authors declare that they have no conflict of interest.

\section{Data availability statement}

The data that support the findings of this study are available on request from the corresponding author. The data are not publicly available due to privacy or ethical restrictions.

\section{References}

Barak, P., Jobe, B.O., Krueger, A.R., Peterson, L.A. \& Laird, D.A. 1997. Effects of long-term soil acidification due to nitrogen fertilizer inputs in Wisconsin. Plant and Soil, 197, 61-69. 
Bertrand, I., Delfosse, O. \& Mary, B. 2007. Carbon and nitrogen mineralization in acidic, limed and calcareous agricultural soils: apparent and actual effects. Soil Biology and Biochemistry, 39, 276-288.

Bessho, T. \& Bell, L.C. 1992. Soil solid and solution phase changes and mung bean response during amelioration of aluminium toxicity with organic matter. Plant and Soil, 140, 183-196.

Burle, M., Mielniczuk, J. \& Focchi, S. 1997. Effect of cropping systems on soil chemical characteristics, with emphasis on soil acidification. Plant and Soil, 190, 309-316.

Butterly, C., Baldock, J. \& Tang, C. 2013. The contribution of crop residues to changes in soil pH under field conditions. Plant and Soil, 366, 185-198.

Butterly, C., Bhatta Kaudal, B., Baldock, J. \& Tang, C. 2011. Contribution of soluble and insoluble fractions of agricultural residues to short-term pH changes. European Journal of Soil Science, 62, 718-727.

Conyers, M., Poile, G. \& Cullis, B.R. 1991. Lime responses by barley as related to available soil aluminium and manganese. Australian Journal of Agricultural Research, 42, 379-390.

Cregan, P., Hirth, J. \& Conyers, M. 1989. Amelioration of soil acidity by liming and other amendments. In: Soil acidity and plant growth (ed. Robson, A.), pp. 205-264. Academic Press, Sydney.

de Caritat, P., Cooper, M. \& Wilford, J. 2011. The pH of Australian soils: field results from a national survey. Soil Research, 49, 173-182.

Doss, B. \& Lund, Z. 1975. Subsoil pH effects on growth and yield of cotton. Agronomy Journal, 67, 193-196.

Haynes, R. \& Mokolobate, M. 2001. Amelioration of Al toxicity and P deficiency in acid soils by additions of organic residues: a critical review of the phenomenon and the mechanisms involved. Nutrient Cycling in Agroecosystems, 59, 47-63.

Hedley, M.J. \& Bolan, N.S. 2003. Role of carbon, nitrogen, and sulfur cycles in soil acidification. In: Handbook of soil acidity (ed. Rengel, Z.), pp. 43-70. Marcel Dekker, New York.

Helyar, K.R. \& Porter, W. 1989. Soil acidification, its measurement and the processes involved. In: Soil acidity and plant growth (ed. Robson, A.), pp. 61-101. Academic Press, Sydney.

Hue, N.V. \& Licudine, D. 1999. Amelioration of subsoil acidity through surface application of organic manures. Journal of Environmental quality, 28, 623-632.

Isbell, R.F. 1996. The Australian Soil Classification. CSIRO Publishing, Melbourne.

Kochian, L.V., Hoekenga, O.A. \& Pineros, M.A. 2004. How do crop plants tolerate acid soils? Mechanisms of aluminum tolerance and phosphorous efficiency. Annu. Rev. Plant Biol., 55, 459-493.

Li, G.D., Conyers, M.K., Helyar, K.R., Lisle, C.J., Poile, G.J. \& Cullis, B.R. 2019. Long-term surface application of lime ameliorates subsurface soil acidity in the mixed farming zone of south-eastern Australia. Geoderma, 338, 236-246. 
Li, J.Y., Masud, M.M., Li, Z.Y. \& Xu, R.K. 2015. Amelioration of an Ultisol profile acidity using crop straws combined with alkaline slag. Environmental Science and Pollution Research, 22, 9965-9975.

Liu, J. \& Hue, N. 2001. Amending subsoil acidity by surface applications of gypsum, lime, and composts. Communications in soil science and plant analysis, 32, 2117-2132.

Magdoff, F. \& Bartlett, R. 1985. Soil pH buffering revisited. Soil Science Society of America Journal, 49, 145-148.

Marschner, B. \& Bredow, A. 2002. Temperature effects on release and ecologically relevant properties of dissolved organic carbon in sterilised and biologically active soil samples. Soil Biology and Biochemistry, 34, 459-466.

Marschner, B. \& Kalbitz, K. 2003. Controls of bioavailability and biodegradability of dissolved organic matter in soils. Geoderma, 113, 211-235.

Matsumoto, H. 2000. Cell biology of aluminum toxicity and tolerance in higher plants. International Review of Cytology, 200, 1-46.

Miyazawa, M., Pavan, M.A. \& Franchini, J.C. 2002. Evaluation of plant residues on the mobility of surface applied lime. Brazilian Archives of Biology and Technology, 45, 251-256.

Noble, A.D. \& Sumner, M.E. 2003. Soil Acidification: The world story. In: Handbook of soil acidity (ed. Rengel, Z.), pp. 1-28. Marcel Dekker, New York.

Nye, P. \& Ameloko, A. 1987. Predicting the rate of dissolution of lime in soil. European Journal of Soil Science, 38, 641-649.

Paul, K.I., Black, A.S. \& Conyers, M.K. 2001. Effect of plant residue return on the development of surface soil pH gradients. Biology and Fertility of Soils, 33, 75-82.

Paul, K.I., Black, A.S. \& Conyers, M.K. 2003. Development of acidic subsurface layers of soil under various management systems. In: Advances in Agronomy, Vol 78 (ed. Sparks, D.L.), pp. 187-214. Academic Press, San Diego, CA, USA.

Pocknee, S. \& Sumner, M.E. 1997. Cation and nitrogen contents of organic matter determine its soil liming potential. Soil Science Society of America Journal, 61, 86-92.

Ratzke, C. \& Gore, J. 2018. Modifying and reacting to the environmental pH can drive bacterial interactions. PLOS Biology, 16, e2004248.

Rengel, Z. \& Tang, C. 2003. Role of plant cation/anion uptake ratio in soil acidification. In: Handbook of soil acidity (ed. Rengel, Z.), pp. 71-96. Marcel Dekker, New York.

Ryan, P.R. 2018. Assessing the role of genetics for improving the yield of Australia's major grain crops on acid soils. Crop and Pasture Science, 69, 242-264. 
Scott, B.J., Ridley, A.M. \& Conyers, M.K. 2000. Management of soil acidity in long-term pastures of southeastern Australia: a review. Australian Journal of Experimental Agriculture, 40, 1173-1198.

Stotzky, G. \& Norman, A. 1961. Factors limiting microbial activities in soil. Archiv für Mikrobiologie, 40, 341-369.

Tang, C., Barton, L. \& McLay, C. 1997. A comparison of proton excretion of twelve pasture legumes grown in nutrient solution. Australian Journal of Experimental Agriculture, 37, 563-570.

Tang, C., Weligama, C. \& Sale, P. 2013. Subsurface soil acidification in farming systems: Its possible causes and management options. In: Molecular Environmental Soil Science. Progress in Soil Science. (eds. Xu, J. \& Sparks, D.L.), pp. 389-412. Springer, Dordrecht.

Tang, C. \& Yu, Q. 1999. Impact of chemical composition of legume residues and initial soil pH on pH change of a soil after residue incorporation. Plant and Soil, 215, 29-38.

Wang, L., Butterly, C.R., Chen, Q., Mu, Z., Wang, X., Xi, Y., Zhang, J. \& Xiao, X. 2016. Surface Amendments Can Ameliorate Subsoil Acidity in Tea Garden Soils of High-Rainfall Environments. Pedosphere, 26, 180191.

Wang, X., Butterly, C.R., Baldock, J.A. \& Tang, C. 2017. Long-term stabilization of crop residues and soil organic carbon affected by residue quality and initial soil $\mathrm{pH}$. The Science of the total environment, 587-588, 502-509.

Wang, X., Tang, C., Mahony, S., Baldock, J.A. \& Butterly, C.R. 2015. Factors affecting the measurement of soil pH buffer capacity: approaches to optimize the methods. European Journal of Soil Science, 66, 53-64.

Wang, Y., Liu, X., Butterly, C., Tang, C. \& Xu, J. 2013. pH change, carbon and nitrogen mineralization in paddy soils as affected by Chinese milk vetch addition and soil water regime. Journal of Soils and Sediments, 13, 654-663.

Whitten, M., Wong, M. \& Rate, A. 2000. Amelioration of subsurface acidity in the south-west of Western Australia: downward movement and mass balance of surface-incorporated lime after 2-15 years. Soil Research, 38, 711-728.

Whitten, M.G. 2002. Amelioration and prevention of agriculturally generated subsurface acidity in sandy soils in Western Australia. The University of Western Australia, Perth, Australia.

Wong, M., Akyeampong, E., Nortcliff, S., Rao, M. \& Swift, R. 1995. Initial responses of maize and beans to decreased concentrations of monomeric inorganic aluminium with application of manure or tree prunings to an Oxisol in Burundi. Plant and Soil, 171, 275-282.

Wong, M. \& Swift, R.S. 2003. Role of organic matter in alleviating soil acidity. In: Handbook of soil acidity (ed. Rengel, Z.), pp. 337-358. Marcel Dekker, New York. 
Wong, M.T.F., Gibbs, P., Nortcliff, S. \& Swift, R.S. 2000. Measurement of the acid neutralizing capacity of agroforestry tree prunings added to tropical soils. Journal of Agricultural Science, 134, 269-276.

WRB, I.W.G. 2014. World Reference Base for Soil Resources. International soil classification system for naming soils and creating legends for soil maps. FAO, Rome.

Xu, J., Tang, C. \& Chen, Z.L. 2006. The role of plant residues in pH change of acid soils differing in initial pH. Soil Biology and Biochemistry, 38, 709-719.

Yan, F., Schubert, S. \& Mengel, K. 1996. Soil pH increase due to biological decarboxylation of organic anions.

Soil Biology and Biochemistry, 28, 617-624. 


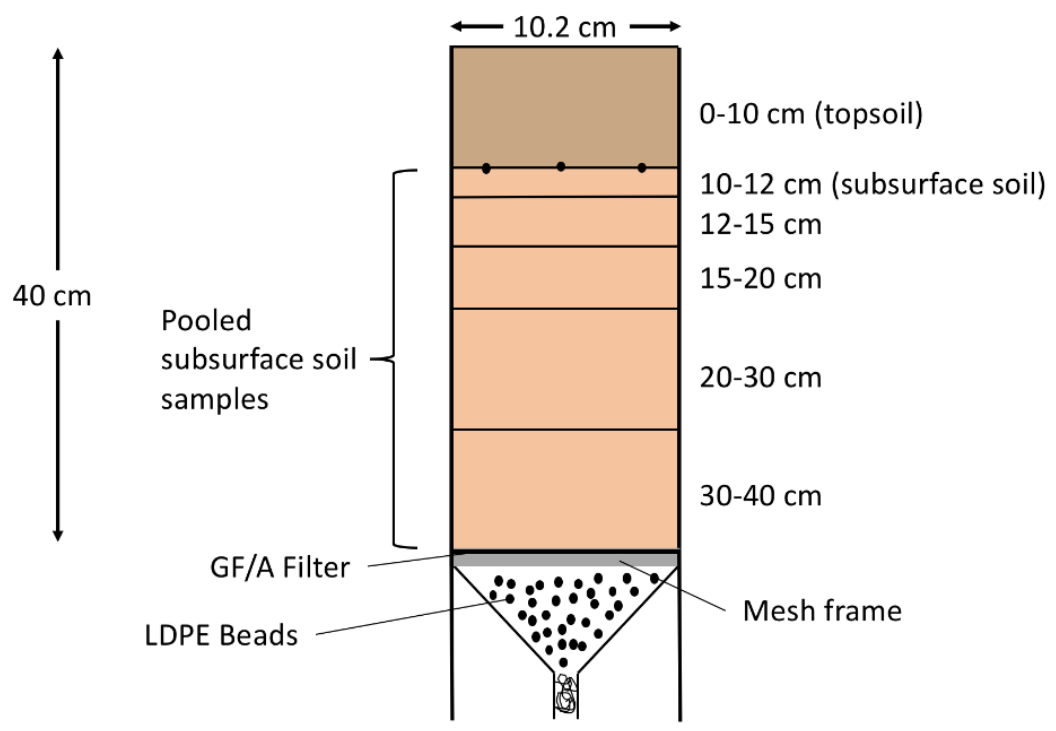

Figure 1 Leaching column design with reconstructed soil profile.

This article is protected by copyright. All rights reserved. 


\section{Soil pH}
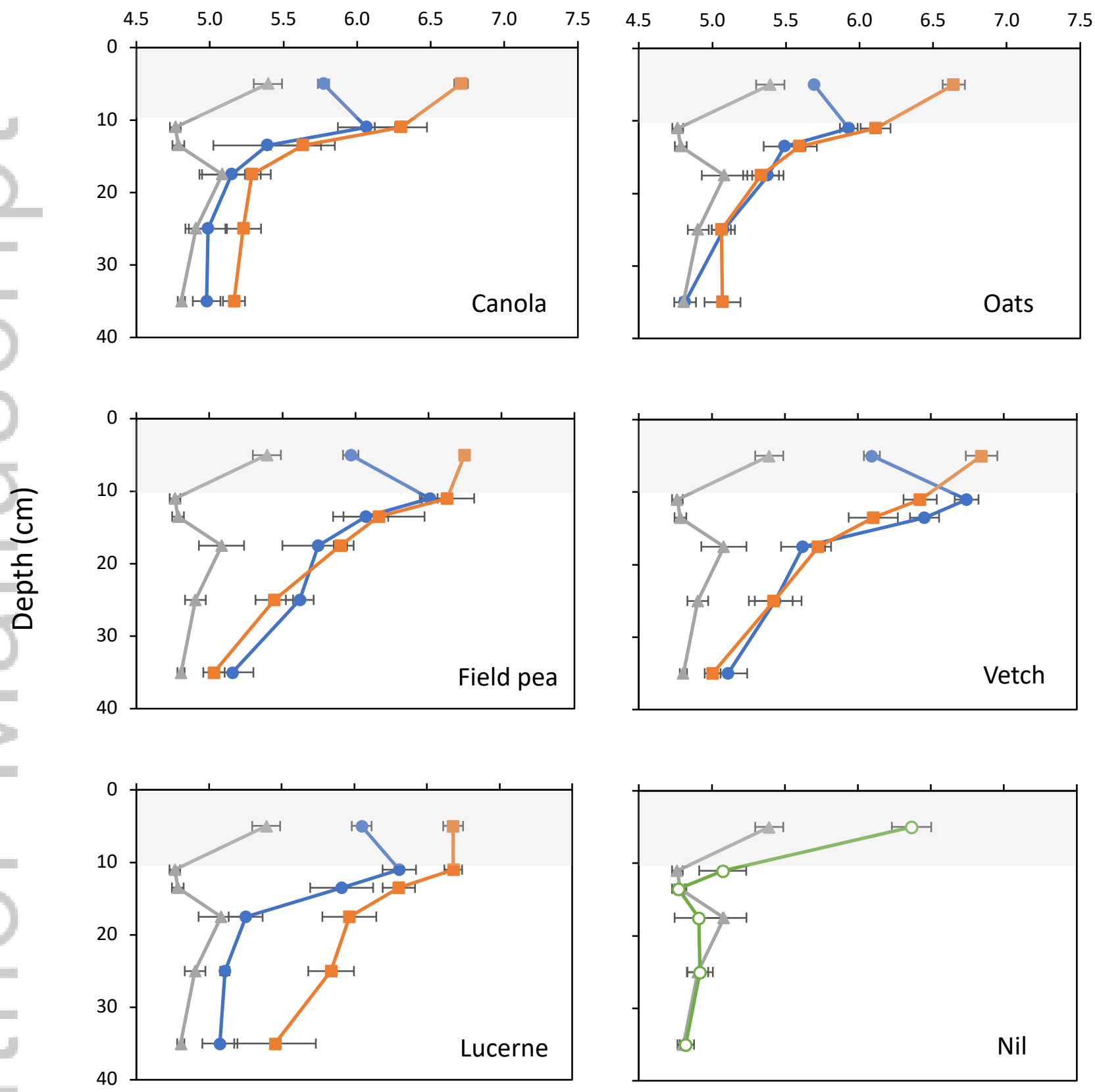

Figure 2 Soil pH (1:5 0.01 $\left.\mathrm{M} \mathrm{CaCl}_{2}\right)$ at six depths $(0-10,10-12,12-15,15-20,20-30$ and 30-40 cm) in Luvisol columns 1 month after amendment $(0-10 \mathrm{~cm}$, shaded grey) with canola, oats, field pea, vetch and lucerne residues (circle + blue lines), corresponding residues plus lime (square + orange lines), non-amended controls (triangle + grey lines) or non-amended controls plus lime (open circle + green line). Horizontal bars indicate \pm standard errors of the mean $(\mathrm{n}=3)$. 


\section{Dissolved organic $\mathrm{C}\left(\mu \mathrm{g} \mathrm{g} \mathrm{g}^{-1}\right)$}
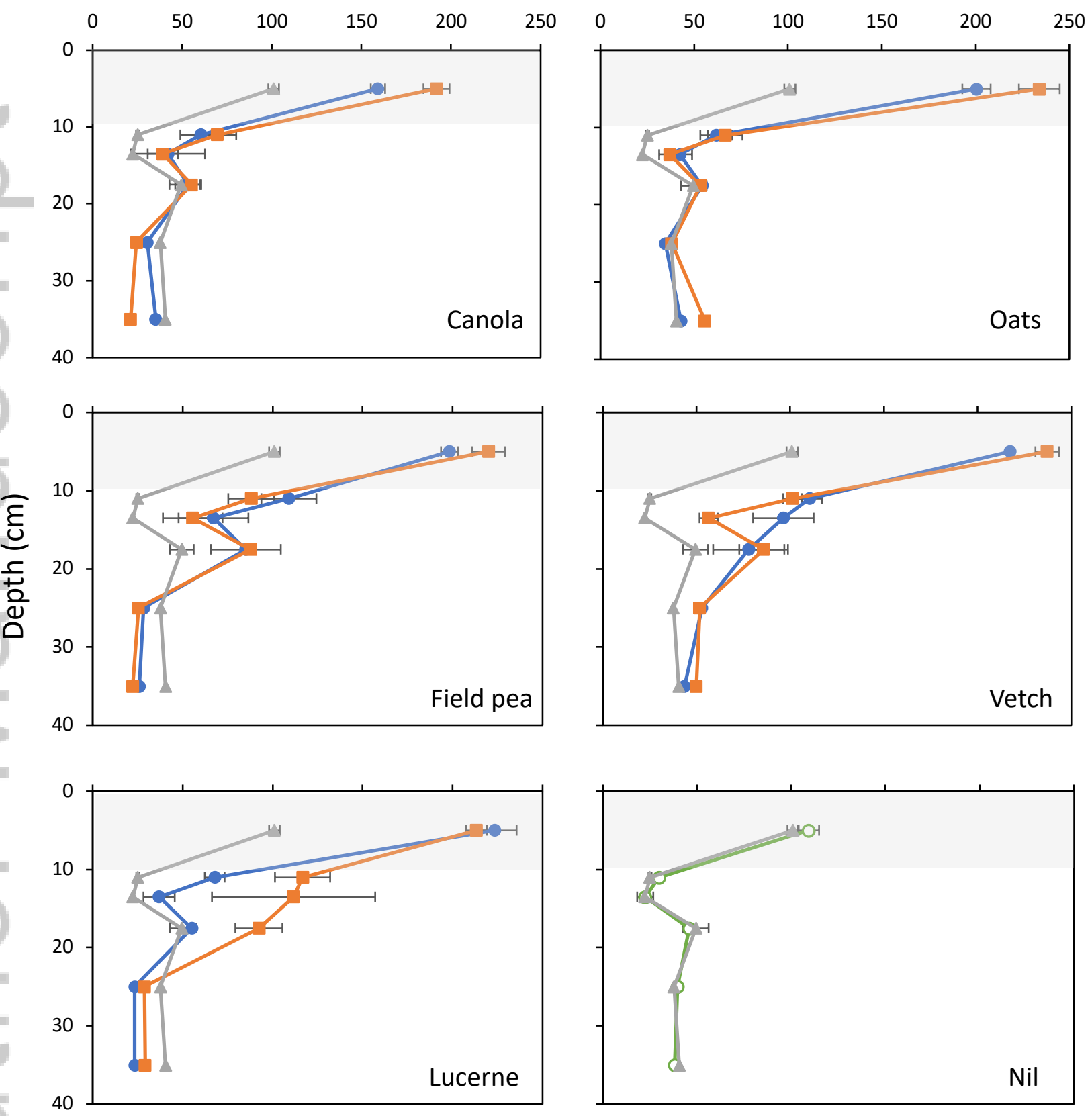

Figure 3 Dissolved organic C (DOC) at six depths (0-10, 10-12, 12-15, 15-20, 20-30 and 30-40 cm) in Luvisol columns 1 month after amendment $(0-10 \mathrm{~cm}$, shaded grey) with canola, oats, field pea, vetch and lucerne residues (circle + blue lines), corresponding residues plus lime (square + orange lines), non-amended controls (triangle + grey lines) or non-amended controls plus lime (open circle + green line). Horizontal bars indicate \pm standard errors of the mean $(\mathrm{n}=3)$. 


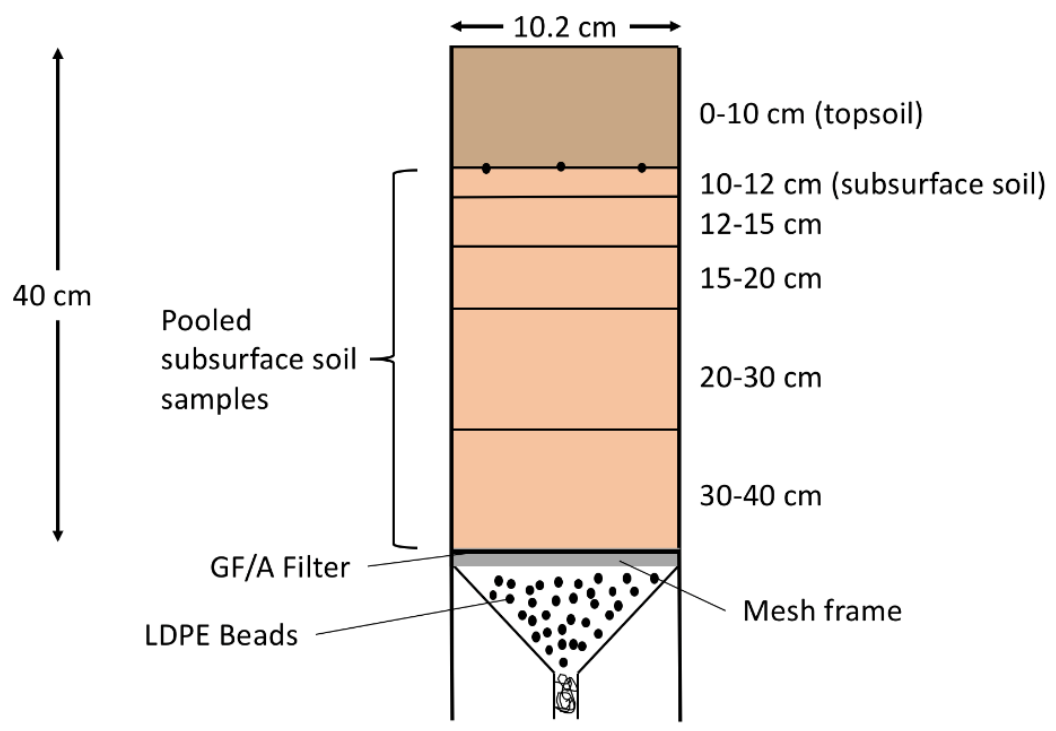

Figure 1 Leaching column design with reconstructed soil profile.

This article is protected by copyright. All rights reserved. 


\section{Soil pH}
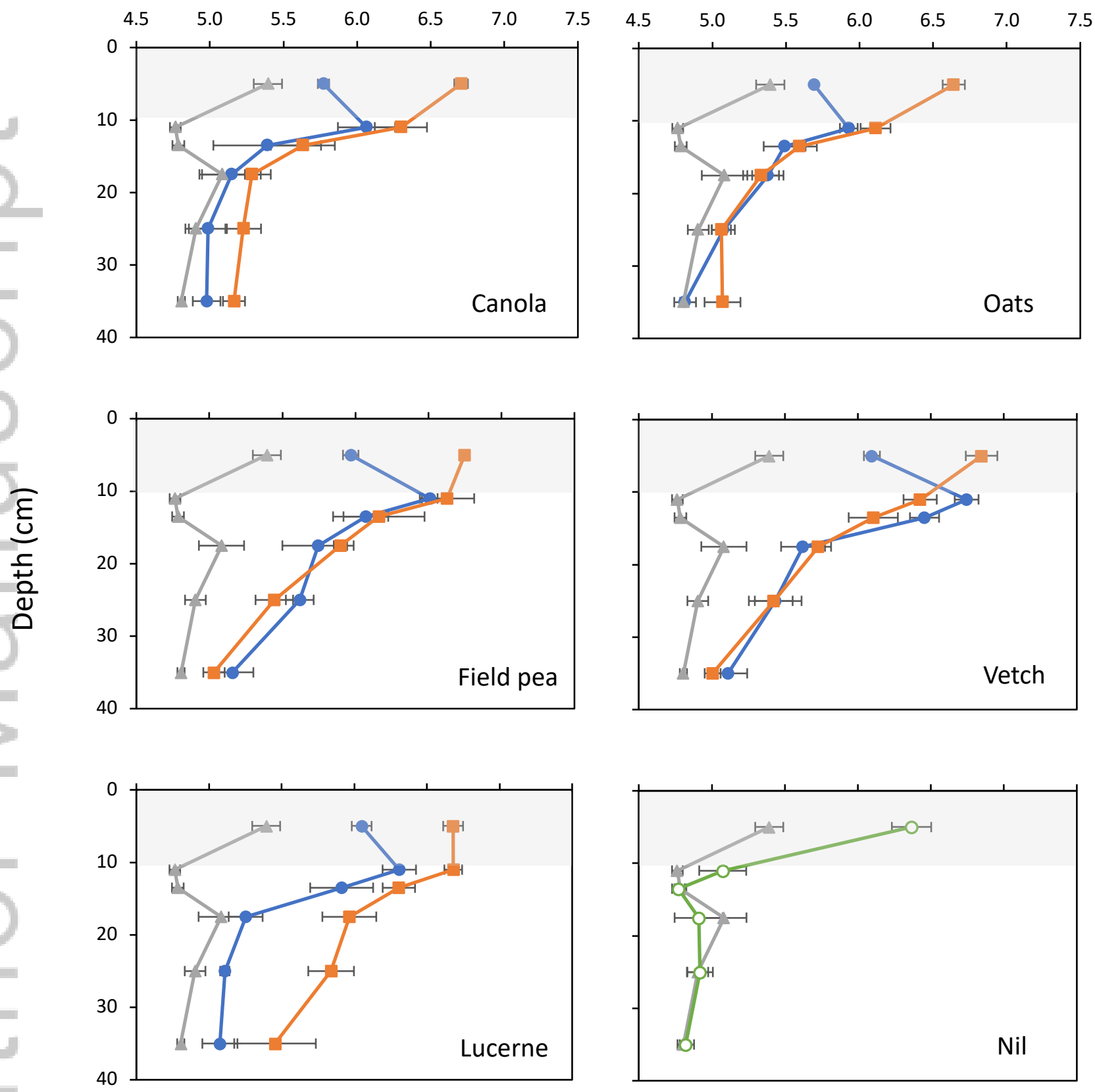

Figure 2 Soil pH (1:5 0.01 $\left.\mathrm{M} \mathrm{CaCl}_{2}\right)$ at six depths $(0-10,10-12,12-15,15-20,20-30$ and 30-40 cm) in Luvisol columns 1 month after amendment $(0-10 \mathrm{~cm}$, shaded grey) with canola, oats, field pea, vetch and lucerne residues (circle + blue lines), corresponding residues plus lime (square + orange lines), non-amended controls (triangle + grey lines) or non-amended controls plus lime (open circle + green line). Horizontal bars indicate \pm standard errors of the mean $(\mathrm{n}=3)$. 


\section{Dissolved organic $\mathrm{C}\left(\mu \mathrm{g} \mathrm{g} \mathrm{g}^{-1}\right)$}
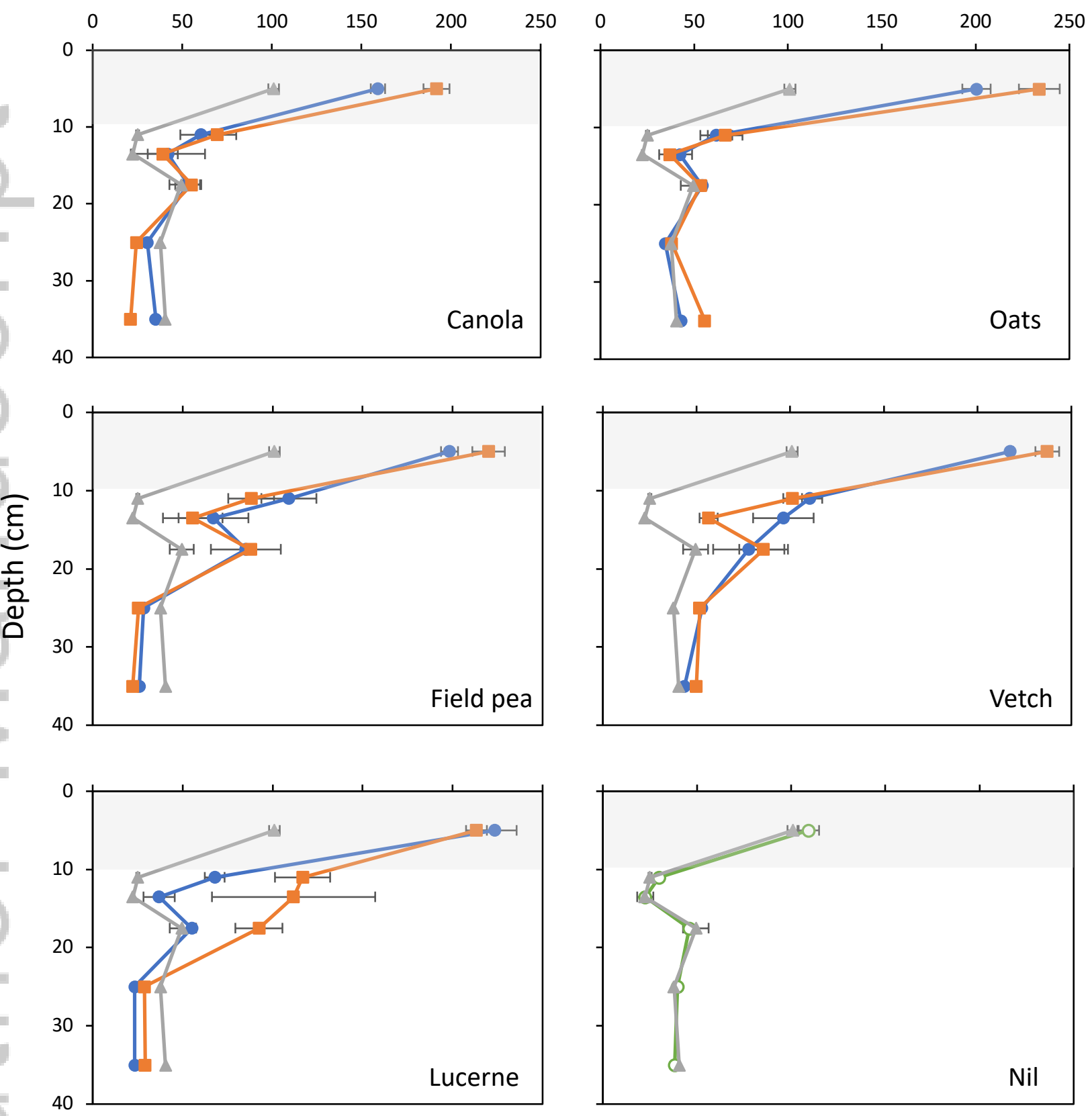

Figure 3 Dissolved organic C (DOC) at six depths (0-10, 10-12, 12-15, 15-20, 20-30 and 30-40 cm) in Luvisol columns 1 month after amendment $(0-10 \mathrm{~cm}$, shaded grey) with canola, oats, field pea, vetch and lucerne residues (circle + blue lines), corresponding residues plus lime (square + orange lines), non-amended controls (triangle + grey lines) or non-amended controls plus lime (open circle + green line). Horizontal bars indicate \pm standard errors of the mean $(\mathrm{n}=3)$. 
Table 1 Chemical properties of soil used in this study.

\begin{tabular}{lccccccr}
\hline Soil & $\begin{array}{c}\text { Depth } \\
(\mathrm{cm})\end{array}$ & $\mathrm{pH}_{\mathrm{CaCl}}$ & $\begin{array}{c}\mathrm{pHBC} \\
\left(\mathrm{mmol}_{\mathrm{c}} \mathrm{kg}^{-1} \mathrm{pH}^{-1}\right)\end{array}$ & $\begin{array}{c}\text { Monomeric Al } \\
\left(\mu \mathrm{g} \mathrm{g}^{-1}\right)\end{array}$ & $\begin{array}{c}\text { Total C } \\
\left(\mathrm{mg} \mathrm{g}^{-1}\right)\end{array}$ & $\begin{array}{c}\text { Total N } \\
\left(\mathrm{mg} \mathrm{g}^{-1}\right)\end{array}$ & C:N \\
\hline Topsoil & $0-8$ & 5.2 & 17.4 & 0.28 & 17 & 1.7 & 10.3 \\
Subsurface soil & $8-15$ & 4.7 & 14.1 & 1.27 & 8 & 1.0 & 7.9 \\
\hline
\end{tabular}


Table 2 Chemical properties of plant residues used in this study.

\begin{tabular}{|c|c|c|c|c|c|c|c|c|c|c|c|c|}
\hline \multirow[t]{2}{*}{ Residue } & Total C & Total N & \multirow[t]{2}{*}{$\mathrm{C} / \mathrm{N}$} & $\mathrm{P}$ & $\mathrm{K}$ & $\mathrm{Ca}$ & $\mathrm{Mg}$ & $\mathrm{Na}$ & $\mathrm{S}$ & $\mathrm{Mn}$ & $\mathrm{Al}$ & \multirow{2}{*}{$\begin{array}{l}\text { Excess cations } \\
\quad\left(\mathrm{cmol} \mathrm{kg}^{-1}\right)\end{array}$} \\
\hline & \multicolumn{2}{|c|}{$\left(\mathrm{g} \mathrm{kg}^{-1}\right)$} & & \multicolumn{8}{|c|}{$\left(\mathrm{g} \mathrm{kg}^{-1}\right)$} & \\
\hline Canola & 446 & 8.7 & 51.6 & 0.37 & 16.1 & 1.8 & 0.83 & 3.50 & 1.48 & 0.02 & 0.02 & 54 \\
\hline Field pea & 442 & 34.6 & 12.8 & 4.01 & 29.4 & 6.0 & 2.14 & 2.57 & 1.95 & 0.01 & 0.20 & 109 \\
\hline Lucerne & 441 & 28.1 & 15.7 & 2.38 & 35.4 & 9.7 & 1.99 & 2.24 & 2.80 & 0.01 & 0.13 & 140 \\
\hline Oats & 436 & 8.2 & 53.2 & 1.74 & 21.3 & 1.3 & 0.63 & 4.92 & 1.04 & 0.02 & 0.03 & 76 \\
\hline Vetch & 440 & 37.3 & 11.8 & 3.82 & 47.2 & 7.6 & 1.81 & 5.31 & 2.48 & 0.00 & 0.09 & 169 \\
\hline
\end{tabular}

${ }^{\mathrm{a}}$ Excess cations is the difference in charge concentration between cations $\left(\mathrm{Ca}^{2+}, \mathrm{Mg}^{2+}, \mathrm{K}^{+}\right.$and $\left.\mathrm{Na}^{+}\right)$and anions $\left(\mathrm{SO}_{4}{ }^{2-}\right.$ and $\left.\mathrm{PO}_{4}{ }^{-}\right)$ 
Table 3 Two-way analysis of variance (ANOVA) of the effects the organic amendments (OrgA) and lime (Lime) and their interactions (OrgA $\times$ Lime) on soil $\mathrm{pHCaCl}_{2}$ and dissolved organic C (DOC) at 1 month for each depth. Values of least significant difference (LSD) of interactions at $P=0.05$ are also presented. Not significant (ns), ${ }^{*}, * *$ and $* * *$ indicate $P>0.05, P<0.05, P<0.01$ and $P<0.001$, respectively.

\begin{tabular}{|c|c|c|c|c|c|c|c|c|c|c|c|}
\hline \multirow{2}{*}{$\begin{array}{l}\text { Depth } \\
(\mathrm{cm})\end{array}$} & \multicolumn{5}{|c|}{$\mathrm{pH}_{\mathrm{CaCl}}$} & \multicolumn{6}{|c|}{ DOC } \\
\hline & OrgA & $\begin{array}{c}\text { LSD } \\
(P=0.05)\end{array}$ & Lime & $\begin{array}{c}\text { LSD } \\
(P=0.05)\end{array}$ & $\begin{array}{c}\text { OrgA } \\
\times \text { Lime }\end{array}$ & OrgA & $\begin{array}{c}\text { LSD } \\
(P=0.05)\end{array}$ & Lime & $\begin{array}{c}\text { LSD } \\
(P=0.05)\end{array}$ & $\begin{array}{c}\text { OrgA } \\
\times \text { Lime }\end{array}$ & $\begin{array}{c}\text { LSD } \\
(P=0.05)\end{array}$ \\
\hline $0-10$ & $* * *$ & 0.151 & $* * *$ & 0.087 & ns & - & - & - & - & $*$ & 20.9 \\
\hline $10-12$ & $* * *$ & 0.256 & $*$ & 0.148 & ns & - & - & - & - & $*$ & 28.3 \\
\hline $12-15$ & $* * *$ & 0.394 & ns & - & ns & $*$ & 36.0 & ns & - & ns & - \\
\hline $15-20$ & $* * *$ & 0.312 & ns & - & ns & $* *$ & 20.8 & ns & - & ns & - \\
\hline $20-30$ & $* * *$ & 0.235 & ns & - & ns & $* * *$ & 10.3 & ns & - & ns & - \\
\hline $30-40$ & $*$ & 0.251 & ns & - & ns & $* * *$ & 8.6 & ns & - & ns & - \\
\hline
\end{tabular}


Table 4 Monomeric Al ( $\mu \mathrm{g} \mathrm{Al} \mathrm{g}{ }^{-1}$ soil) in six layers of Luvisol columns at 1 month following amendment with canola, field pea, lucerne, oats, vetch residues and non-amended (Nil), with and without lime. Values in brackets are standard deviations of the mean ( $\mathrm{n}=3$ ). Two-way analysis of variance (ANOVA) of the effects the organic amendments (OrgA) and lime (Lime) and their interactions (OrgA × Lime).

\begin{tabular}{|c|c|c|c|c|c|c|c|}
\hline $\begin{array}{l}\text { Organic } \\
\text { amendment }\end{array}$ & Lime & \multicolumn{6}{|c|}{$\begin{array}{l}\text { Monomeric Al } \\
\left(\mu g \mathrm{Al} \mathrm{g}^{-1} \text { soil }\right)\end{array}$} \\
\hline Canola & No lime & $0.01(0.00)$ & $0.02(0.01)$ & $0.25(0.22)$ & $0.38(0.35)$ & $0.41(0.23)$ & $0.34(0.18)$ \\
\hline \multirow[t]{2}{*}{ Field pea } & No lime & $0.01(0.00)$ & $0.01(0.01)$ & $0.01(0.02)$ & $0.03(0.03)$ & $0.05(0.02)$ & $0.23(0.15)$ \\
\hline & Lime & $0.01(0.01)$ & $0.01(0.00)$ & $0.02(0.05)$ & $0.02(0.00)$ & $0.08(0.07)$ & $0.32(0.17)$ \\
\hline \multirow[t]{2}{*}{ Lucerne } & No lime & $0.01(0.00)$ & $0.01(0.01)$ & $0.04(0.06)$ & $0.15(0.06)$ & $0.19(0.07)$ & $0.28(0.19)$ \\
\hline & Lime & $0.01(0.00)$ & $0.01(0.01)$ & $0.00(0.00)$ & $0.01(0.00)$ & $0.03(0.02)$ & $0.17(0.02)$ \\
\hline \multirow[t]{2}{*}{ Vetch } & No lime & $0.02(0.01)$ & $0.01(0.00)$ & $0.02(0.01)$ & $0.04(0.04)$ & $0.11(0.07)$ & $0.28(0.16)$ \\
\hline & Lime & $0.01(0.01)$ & $0.00(0.01)$ & $0.02(0.02)$ & $0.02(0.01)$ & $0.10(0.05)$ & $0.39(0.12)$ \\
\hline \multirow[t]{2}{*}{ Nil } & No lime & $0.04(0.03)$ & $0.81(0.18)$ & $0.79(0.32)$ & $0.37(0.16)$ & $0.49(0.16)$ & $0.56(0.05)$ \\
\hline & Lime & $0.02(0.00)$ & $0.35(0.28)$ & $0.78(0.17)$ & $0.67(0.52)$ & $0.60(0.12)$ & $0.64(0.16)$ \\
\hline LSD for any & eans $(P=0.05)$ & 0.02 & 0.16 & 0.19 & 0.37 & 0.18 & 0.27 \\
\hline \multicolumn{8}{|c|}{ Significance level } \\
\hline
\end{tabular}

This article is protected by copyright. All rights reserved. 


\section{University Library}

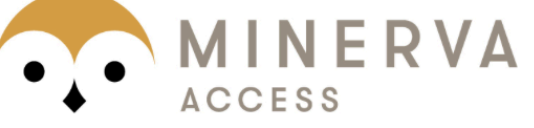

A gateway to Melbourne's research publications

Minerva Access is the Institutional Repository of The University of Melbourne

Author/s:

Butterly, CR;Costello, B;Lauricella, D;Sale, P;Li, G;Tang, C

Title:

Alkalinity movement down acid soil columns was faster when lime and plant residues were combined than when either was applied separately

Date:

2020-02-28

\section{Citation:}

Butterly, C. R., Costello, B., Lauricella, D., Sale, P., Li, G. \& Tang, C. (2020). Alkalinity movement down acid soil columns was faster when lime and plant residues were combined than when either was applied separately. EUROPEAN JOURNAL OF SOIL SCIENCE, 72 (1), pp.313-325. https://doi.org/10.1111/ejss.12945.

Persistent Link:

http://hdl.handle.net/11343/275468 